\title{
A GRÓF HUNYADY CSALÁD SZEREPE A BALATONI TURIZMUS LÉTREJÖTTÉBEN
}

\author{
Kaposi Zoltán \\ Pécsi Tudományegyetem, Közgazdaságtudományi Kar, Marketing és Turizmus Intézet \\ MTA doktora, intézeti igazgató, egyetemi tanár; kaposi.zoltan@ktk.pte.hu
}

DOI: $10.15170 /$ TVT.2021.06.03.01

\begin{abstract}
Absztrakt
A dél-balatoni fürdőélet fejlődése az 1880-as években kezdődött meg. A Balaton magas vízszintje, a tó melletti hatalmas mocsarak sokáig akadályozták a turizmus nekilendülését. A vasút kiépítése (1861) és a Sió-zsilip átadása (1863) alkalmat adott az elörelépésre. A térség fürdőéletének fejlődésében nagy szerepe volt a part menti vidék nagybirtokosainak. A tanulmányban a kezdeteket kutatjuk. A kéthelyi és balatonszemesi uradalom földesura, gróf Hunyady Imre volt az első, aki Balatonberényben nyaralót épített, s mellette szép parkot alakított ki. Hunyady gróf aktív szerepet játszott Berény és Szemes fejlesztésében. A part menti területeket parcelláztatta, hogy azokon villákat lehessen építeni. Balatonberényben saját gőzhajójának kikötőt épített, s a hajót fizetős kirándulásokra használták. A közvetlen parti területet fásította. Törekvései eredményeképpen két évtized alatt a falvakban jelentős fürdőtelep jött létre, amelyben sokan láttak vállalkozási lehetőséget. A part menti sávra szállodák, vendéglők, panziók épültek. A vendégek zöme Budapeströl, Marcaliból, Nagykanizsáról érkezett. A falusi parasztság számára új jövedelemszerzési lehetőség volt a fizetővendéglátás. A turizmus fellendüléséhez szükség volt az ellátás biztosítására. A gróf uradalmainak kertészete szállította a zöldségféléket, gyümölcsöket, az uradalmi mészárszékröl került ki a hús, s a borellátás is a gróf Baglas-hegyi pincészetéből valósult meg. Nagy előrelépés volt a polgári fürdőegyesületek megalakulása, a 20. század elején már ezek látták el a települések gondozását.
\end{abstract}

Kulcsszavak: Balaton, uradalom, turizmus, Hunyady Imre, fejlödés 


\begin{abstract}
Lakeside tourism on the southern shore of Lake Balaton came to life in the 1880s. High water levels of Lake Balaton and swamps near the lake have prohibited the growth of tourism. The construction of the railway (1861) and the Sio flood gate (1863) gave opportunities for a step forward. Large estate owners around the southern shores played a major role in the development of tourism. In this study we examine the beginnings. Count Imre Hunyady, owner of the estate of Kéthely and Balatonszemes was the first one who built a summer house in Balatonberény and a nice park next to it. Count Hunyady played an active role in the development of Berény and Szemes too. He subdivided the lands on the shores in order to have villas built on them. He also had a port constructed for his own steam boat in Balatonberény and it was used as an excursion ship to attract paying customers. He also had trees planted on the shores. As a result of his efforts a significant resort came to life in the villages in just two decades which attracted many entrepreneurs. Hotels, inns, restaurants and pensions were built on the shores. Most of the customers arrived from Budapest, Marcali and Nagykanizsa. For the rural peasant communities hosting guests was a new source of income. The development of tourism required more supplies. Vegetable farms belonging to the Count's estates supplied fruits and vegetables, the butchery of the estate provided the meat and wine came from the vineries of the Count too. A great step ahead was the foundation of civil bathing associations which managed these settlements in the beginning of the twentieth century.
\end{abstract}

Keywords: Balaton, manor, tourism, Imre Hunyady, development 


\section{Bevezetés: A fürdőélet fejlődése Magyarországon}

„Nincs a kerek földnek még egy olyan országa, melynek buja termékenysége, természeti kincsekben való gazdagsága vetekedhetnék Magyarországéval." Ezekkel a romantikus sorokkal indul az 1911-ben kiadott Magyar Fürdő-Kalauz, amelyben a szerkesztő-szerző, Erdős József tételesen felsorolja és bemutatja a világháború előtti években müködő legjelentősebb magyar fürdőket és gyógyhelyeket. A szerző a hazai fürdőket dicsérve megállapította róluk, hogy adottságaikban felveszik a versenyt a nyugati fürdőkkel. Érezve a helyzet fonákságát, rámutatott egy fontos problémára is: „Hogy Magyarország ennyi kedvező körülmény ellenére még mindig nem elsö fürdöországa Európának, annak oka elsősorban az a végzetes elöitélet, melylyel a tehetös magyar fürdöközönség, egy teljesen indokolatlan és félszeg divatáramlatnak hódolva, a külföldi fürdők látogatásához ragaszkodik”. (ERDÖS 1911:3-4) A fürdőkalauz szerzője úgy látta, hogy erősebb felvilágosító propagandával e nehézségek leküzdhetők. Véleményének hátterét az adhatta, hogy a 19. század vége felé egyre-másra nyíltak a hazai fürdőhelyek, új szokások jöttek divatba, s néhány térség esetében gyors fejlődés ment végbe.

Mivel a Habsburg Birodalom keretébe ágyazódó Magyarország jövedelemtermelő teljesítménye messze elmaradt Ausztriáétól, ezért olyan jelentős vásárlóerővel bíró polgári középréteg, mint Nyugaton, nem alakulhatott ki. Nem véletlen, hogy országunkban a fent jelzett folyamatok csak visszafogottan mentek végbe. Ausztriában időben előbb és méretben jóval nagyobb fürdőrendszer alakult ki, mint Magyarországon; Karlsbad, Bad Ischl, Bad Gastein stb. a Monarchia és Németország elitjeinek fürdői voltak, de kétségtelen, hogy az ausztriai és csehországi fürdőket magyar arisztokraták, ipari- és kereskedelmi nagyvállalkozók, magas politikai állásokat betöltők is gyakran látogatták. (KÓSA 1999:175-177)

Magyarországon a török kor után az első fürdők a nagyobb és ismert gyógyforrások mellett már a 18. század második felében létrejöttek, de ezeknek akkor még nem volt nagy hatásuk. A 19. században meginduló gazdasági növekedés, a javuló létkörülmények, s a természetről való gondolkodás változása révén azonban már nálunk is egyre több fürdő, gyógyfürdő jöhetett létre. A gyorsan emelkedő társadalmi igények, a külföldi példák utánzása nagy szerepet játszott a hazai fürdőkultúra fejlődésében. Még az olyan, relatíve elmaradott területeken, mint amilyen a Dél-Dunántúl volt, jelentős erőfeszítések történtek fürdők kialakítására. A Zala megyéhez tartozó Balatonfüred forgalma az 1830-as évektől lendült föl, amikor a térségben élő középbirtokosok, vármegyei tisztségviselök, politikusok stb. egyre nagyobb számban jelentek meg a településen. (HUDI 1989:120, 1989:131, BALÁZS-KOVÁCS 2013:214) A Horváth- és Tallián-házak mellett egyre több épületet emeltek, létrehozták a kikötőt, árvízvédelmi töltést építettek, parti sétányt és sétateret hoztak létre, nagyvendéglőt stb. adtak át, amelyek révén a település gyors fejlődésének indult. De említhetjük Harkányfürdő esetét is: a siklósi uradalomhoz tartozó Harkányban a mocsarakkal teli térség lecsapolása közben, 1823-24-ben fedezték föl azt a gyógyvizet, amelyre ráépülhetett egy hosszú távú fejlesztési program. Batthyány Antal gróf 55 hold területet jelölt ki a fürdő kialakítására. (PATKOVICS 1846:162) Az első év végére felhúzták a fürdőépületet; 1828-ra pedig már 28 szobás szállóval is rendelkezett a földesúr. (SZITA 1973)

A Kiegyezés után gyorsan szaporodtak a hazai fürdőhelyek. Földrajzilag szemlélve a fürdők terjedését, nagy szerepe volt a Magyarországhoz tartozó tengerparton Abbáziának és Crikvenicának, mindkét fürdő egyedi szubalpin klímája vonzotta a gazdagabb, föleg arisztokrata vendégeket. 1873 után, amikor megnyílt a Buda-Fiume vasútvonal, már viszonylag könnyen elérhető volt az Adria. A tóparti lehetőségek a Fertő tó és az erdélyi Medve tó partján is nagy turisztikai vonzerővel bírtak (a Balatonról külön szólunk majd). E korszakban nyíltak meg a magaslati üdülőhelyek, amelyek közül kiemelkedtek a Magas-Tátra fürdői. Tipikus nagyvárosi vonássá vált a fürdő: a leghíresebbek Budapesten, Nagyváradon és Pozsonyban 
nyíltak, de az 1860-70-as évektől már a hazai középvárosokban is megjelentek a közfürdők. Pécsett 1858-ban Engel Adolf vállalkozó a Balokányban uszodát épített, amit a katonaság és a polgárság is használhatott. (VARGA 2021:59-60) E fontosabb típusok között sokszor hatalmas minőségi különbségek voltak. A 19-20. század fordulójára a mintegy 200 hazai fürdőhely kialakulása egyértelműen jelzi a társadalmi igények szélesedését. (ERDÖS 1911) A hazai fürdőlátogatók száma gyorsan emelkedett: 1900-ban 165.422, 1905-ben már 226.153 föt regisztráltak. (MSÉ 1900, 1905)

\section{A dél-balatoni térség átalakítása a 19. század második felében}

Közismert, hogy a Balaton térsége az 1860-as évek elött egészen más formát mutatott, mint a mai időkben. A Somogy megyei oldalon a néhány helyen meglévő magasabb partfalat leszámítva a Balaton partja szinte teljesen szabályozatlan volt. A part mentén homokturzások alakultak ki, amelyeket a víz sokszor átjárt. (SZAPLONCZAY 1914:21) Korabeli térképek tanúsága szerint a Nagyberek és a Kis-Balaton sokáig nem vált el a tó többi részétől; a Balatonnak nem volt természetes lefolyása, ezért a parttól délre lévő területeken hatalmas mocsarak, lápok képződtek. Egy-egy nagyobb szárazság során a mocsarakban zsombékos szigetek képződtek, de voltak olyan időszakok is, amikor ezek a kiemelkedések több évre is száraz szigetek maradtak. Nem véletlen, hogy a földtulajdonosok által igényelve, de az állam által is felismerve már a 18. század közepétől születtek javaslatok a tó vízszintjének csökkentésére. (HALÁSZ 2010) Elkészültek az első nagy tervek a beavatkozásra, amelynek meghatározó motívuma a Sió, mint természetes levezető csatorna kiépítése, valamint a Sióhoz kapcsolódó egyéb folyók, patakok (Kapos, Koppány stb.) szabályozása volt. (VIRÁG 2005:222-258) Az 1820-as években megkezdték a térség vízszabályozását. Az 1827. évi részletes területfelmérés során a Balaton somogyi oldalán 39.561 kat. hold vizes területet, berket, bozótot mértek fel, s ebből 5500 hold tartozott a témánk szempontjából kiemelt fontosságú gróf Hunyady család uradalmaihoz. (VIRÁG 2005:239-242) A lecsapolások révén óriási területek kerültek szárazra, amelyeket döntően állattartásra lehetett hasznosítani.

A balatoni térség átalakításához az 1850-es évek világgazdasági konjunktúrája idején a hazai vasútfejlesztés adta az újabb lökést. A Rothschild érdekeltségü Déli Vasút Társaság fejlesztései során viszonylag gyorsan megépítette a Buda-Nagykanizsa-Pragerhof vasútvonalat, amellyel közvetlenül tudott rácsatlakozni a Bécs-Trieszt vonalra, s így jelentős külkereskedelmi forgalmazásra nyílt lehetősége. (KAPOSI 2014:221) A vonal a Balaton déli partján haladt, a korábbi országút nyomvonalában. 1858-61 között zajlott az építkezés, amihez töltésépítés és parterősítés is kellett. A következő pár év kedvezőtlen természeti folyamatai, a jeges árvizek azonban sok helyen megrongálták a vasúti felépítményt, ezért lépéseket kellett tenni a százéves projekt, a vízszintcsökkentés érdekében. Végül is 1863-ban átadták a Sió-zsilipet, amellyel lehetővé vált a Balaton vízszintjének szabályozása, a fölös víz leengedése, ugyanakkor megkezdődhetett a szárazra került területek hasznosítása. (BARANYAI 1959:340, KÁROLYI 1973:262-263)

A vízszint csökkentésével a Nagyberek és Kis-Balaton térségének adottságai is megváltoztak: a nagyon alacsonyan fekvő, a Balaton által rendszeresen elöntött délnyugati partvidéken is egyre több új területhez jutottak hozzá a földtulajdonosok. Mindez persze nem jelentette a folyamat végét, hiszen a Balatontól most elválasztott berkek kezelése továbbra is óriási feladat maradt. Erre hozták létre 1864-ben a Balaton keleti bozót-lecsapoló és a Balaton nyugati bozótlecsapoló társulatot. (SZAPLONCZAY 1914:28-29) Hosszú időbe telt, amíg sikerült a tó vízszintjének beállítása; ha túl sok vizet engedtek le, akkor valóságos homoksivatagok keletkeztek a déli parton, amelyek már sokszor a tulajdonosok érdekeit is sértették; máskor meg a tó a magas vízszintje miatt jelentős területeket öntött el, amivel akadályozta a mezőgazdasági munkákat. Mivel a dél-balatoni földek jelentős része a nagybirtokosok tulajdonában volt, ezért 
nagyobb méretű tájátalakítás, lecsapolás, vagy az ezt követő fürdőfejlesztés csakis általuk történhet.

\section{A földtulajdon és a földhasználat változásai}

Fontos kérdés volt persze, hogy kié is egy adott terület, s a földekhez milyen hasznosítási jogok kapcsolódnak. A polgári forradalom előtt egyszerü volt a helyzet: a Balaton mellett lévő földek teljes egészében világi vagy egyházi földesurak tulajdonában voltak, $\mathrm{s}$ a tóra dülö földesúri birtok a tó vizének feléig is jogilag hozzájuk tartozott. E földeken bármiféle változtatást csakis a földesurak engedélyével lehetett végezni, a kezdeményezők is maguk a tulajdonosok voltak. A dél-balatoni falvak döntő többsége néhány nagyobb uradalom részét képezte. Szentgyörgy és Keresztúr a keszthelyi Festetics uradalomhoz, Berény, Újlak, Szemes és Szárszó a kéthelyi Hunyady-uradalomhoz; Földvár a Széchényiekhez; Orda, Csehi, illetve Lelle fele a szöllősgyöröki Jankovich-birtokhoz; Fonyód a Lengyeltóti központú, előbb Inkey, később Zichy-uradalomhoz tartozott. A Szántódtól keletre lévő települések pedig a Veszprémi Püspökség, a Káptalan és a Tihanyi Apátság birtokai voltak. (MNL SML IV. 1.h. 39. Ö. 282283.) A nagybirtokok sorát csak néhol szakította meg egy-egy középbirtok, így például Boglár több középbirtokosé (Bárány-, Körmendy-, később a Gaál-család), Lelle egy része a Szalay családé volt. Ez egyben azt is jelentette, hogy a dél-balatoni falvak hatalmas, sokszor 100 ezer holdnál is nagyobb uradalmi komplexumokba illeszkedtek be. (KAPOSI 2019:12)

848 után azonban részben megváltozott a helyzet. Az áprilisi törvények révén a korábbi úrbéres földeket (belső házhely, szántó, rét) kiemelték a tradicionális nagybirtokból, s ezek a földek a továbbiakban önálló polgári tulajdont képeztek; e földekhez az 1850-60-as években a közös földek szétválasztása után jelentős legelő- és erdőtulajdon is hozzáadódott. A szőlőjogokat is rendezték, s a parasztoknak (polgároknak) már tulajdon szölöjük is lehetett. (KAPOSI 2002:165) Mindez azt jelentette, hogy az 1870-es évektől már két tulajdonosi kör volt érdekelt a belvíztelenítésben: a régi földesurak, akik továbbra is hatalmas méretü földekkel rendelkeztek, illetve a falvakban élő parasztok, paraszti közösségek vagy más polgárok. Az egyházi és hitbizományi földeket leszámítva bárki bármilyen földet értékesíthetett vagy vásárolhatott. A gazdasági erő persze továbbra is a földesuraknál volt, a nagybirtokosok földjeik méretéből következően más lehetőségekkel rendelkeztek, mint a helyi falusi népesség.

\section{A gróf Hunyady család, mint földtulajdonos}

Közismert a balatoni fürdőélet kutatói számára az a megállapítás, miszerint a déli parton az első állandó nyaralóépületet gróf Hunyady Imre, a kéthelyi uradalom tulajdonosa építette 1881-82ben. Jogos lehet a kérdés: ki is ez a Hunyady gróf, s tevékenysége milyen hatást gyakorolt a környező településekre?

A Felső-Magyarországról származó Hunyady-család a 18. század derekán szerezte meg Somogy megyei birtokait. A négy birtokkerületböl (Kéthely, Faluszemes, Somogyszil, Hosszúfalu) álló hatalmas méretü uradalom a 19. század elején 62.250 holdat tett ki. (MNL SML IV. 1.h. 39. Ö. 282-283.) A família nagyjából hasonló méretü birtokkal rendelkezett északon, Ürményben is, s ezen kívül voltak még Heves megyében is kisebb földjeik. ( $\mathrm{T}$. MÉREY 2012:16) A Somogy megyei birtokközpont Kéthelyre került, amely később a család nevében nemesi előnévként is megjelent. A családi kastélyt a Kéthely melletti Sári pusztán építették föl az 1780-as években. A barokk stílusú, U-alakú kastély ma is áll; meglehetősen leromlott állapotban szociális otthonként funkcionál. A gróf Hunyady-birtok az 1840-es években két részre szakadt. Az akkori két tulajdonostestvér közül Hunyady Ferenc az osztozásnál neki jutott déli birtokokat 1844-ben eladta a bécsi bankár Sina Györgynek. (KAPOSI 2019:28) A grófi birtokok északi részei, Kéthely és a Balaton déli partjának közepén 
fekvő Faluszemes (ma Balatonszemes) viszont a család kezében maradt. Ezek együttes terjedelme 1893-ban 30.781 holdat tett ki. (GAZDACÍMTÁR 1893)

A fürdőturizmus megteremtésében nagy szerepet játszó Hunyady Imre gróf 1827-ben született Bécsben. Neveltetése a korban megszokott arisztokrata minták szerint zajlott, amelynek a királyi udvar iránti hüség meghatározó eleme volt. A több nyelven beszélő, művelt, NyugatEurópát megjárt gróf számára a katonai pálya magától értetődő volt: a karrier során alezredesi rangig jutott, s egyben a király egyik szárnysegédje lett. Felesége radványi gróf Győry Felicie (1842-1913) csillagkeresztes és palotahölgy volt. Hunyady gróf pályafutását végig kísérték a különböző magas rangú kitüntetések. 1858-ban kapta a császári és királyi kamarás címet, majd később „Ő Felsége Valóságos Belső Titkos Tanácsosa.” lett. A gróf tagja volt a förendi háznak. Bensőséges körökben csak „sportsman”-nek nevezték, amit föleg a hazai lótenyésztés fejlesztésében játszott szerepével érdemelt ki, hiszen hosszú éveken át a Magyar Lovaregylet tagja és versenyistálló tulajdonos is volt. A Hunyadyak vonzódása a lótartáshoz és a lovassporthoz régi keletű: 1814-1821 között Ürményben ők rendezték Közép-Európa első lóversenyeit. (Ma is rendeznek gróf Hunyady József emlékversenyt, sőt Batthyány-Hunyadydíj is létezik.) A gróf tagja volt az OMGE igazgatóságának. (VV 1902. 06. 11.) Hunyady Imre 1902. június 8-án hunyt el, családtagjaihoz hasonlóan a mesztegnyői templom alatti családi sírboltban helyezték örök nyugalomra. (BV 1902. 06. 15.) Két fia és két lánya közül József (1873-1942) vitte tovább a Somogy megyei birtokokat. József gróf szenvedélye a vitorlázás volt, 1912-ben a balatonszemesi Balatoni Yacht Club is az ő kezdeményezésére alakult. József gróf sokáig a balatoni térség egyik legnagyobb bortermelöje volt.

\section{Birtokgazdálkodás és a balatonberényi fürdőfejlesztés}

A Hunyady-birtokok neve az idők során egybeolvadt a jól kezelt, modern agrárnagyüzem fogalmával. A fejlesztések fontos eleme volt a tájátalakítás. Még a nagy lecsapolások megindulása előtt a Hunyadyak már jelentős területátalakítást végeztek. Az 1840-50-es években a kéthelyi uradalom Marót pusztáján 800 hold haszontalan erdőt irtottak ki, ugyanakkor 300 hold vizes bozótot szüntettek meg. Mesztegnyőn 600 hold erdő mellett 200 hold vizes bozótot tüntettek el, utóbbiból rét és legelő lett. A kéthelyi és a sári gazdaságoknál 3000 hold vizes bozótból a lecsapolás által 1855-ig már egyharmadában marhalegeltetésre alkalmas száraz terület lett. (GALGÓCZY 1855:382) De legalább ennyire fontos volt a modern technikák alkalmazása is, hiszen ebben a korszakban a gazdasági-üzemi előrelépéshez a termelékenység javítására volt szükség. Az 1850-es évek első felében már belga és Zugmayer ekéket használtak. A szántóföldi gazdálkodásban vetésforgót alkalmaztak, a földek nagy részét trágyázták. A ma is közismert Baglas-hegyen jó minőségü szőlőtermelést folytattak, s a bort magas áron tudták értékesíteni. 1855-ben 10.000 darab juhot és 600 szarvasmarhát tartottak, utóbbiak között 25 darab svájci tehén is volt (tejtermelés). Marót pusztán 1855-ben már gőzerővel müködő szeszgyáruk is volt. (GALGÓCZY 1855:383)

A kéthelyi minőségi gazdaság híre messzire elért. A 19-20. század fordulója környéki adatok is azt mutatják, hogy hogy a Hunyady-birtok az 1880-a évek közepéig tartó agrárkonjunktúra, majd az azt követő tíz éves recesszió alatt és után is a jobb nagyüzemek közé tartozott, amely ugyanakkor jelentős jövedelmet hozott tulajdonosának. 1895-ben a kéthelyi uradalomban 479 cselédet foglalkoztattak. A gazdaság gőzgépekkel, cséplőszekrényekkel, járgányokkal volt felszerelve; 18 vetőgépet, 233 ekét használtak. Szecskavágók, boronák, hengerek segítették a müvelést, nem is beszélve a 120 igás szekérről. Kiterjedt állattartás folytattak: 1652 szarvasmarhát, 152 lovat, 2357 sertést és 4966 juhot tartottak. A kéthelyi és a mesztegnyői gazdaságot saját kezelésben tartották, míg a balatonszemesit bérbe adták. (GAZDACÍMTÁR 1895:106-107) A világháború előtti időszakban még szélesebbé vált az agrárnagyüzem termelése: megjelentek az intenzív müvelés újabb elemei: a hagyományos agrártermékek 
mellett már 580 holdon termeltek cukorrépát, 100-100 holdon dohányt és cikóriát, 10 holdon pedig cirokot. A lóállomány fele hidegvérü, másik fele angol telivér volt; országos hírü volt ugyanakkor a 109 darabos ménesük. A szarvasmarhaállományban 180 berni tehén is volt, (UJVÁRY 1914:321-322) amellyel számos vásári és kiállítási díjat nyertek. (Lásd: KT számait) A napi 1200 liter tejet vasúton szállították Budapestre. Magas minőségü volt 4500 darabos merinói juhállomány is. A balatoni halászatot bérbe adták. Az uradalomnak jelentős borászata volt, ahol a filoxéra utáni szőlőkből készítettek bort. Szinte már angliai nagybirtokokat idéz az is, hogy több iparvállalat is megjelent az uradalomban: volt egy vízimalom, egy gőzmalom, évi 1.5 millió darab tégla kapacitású téglagyár, s emeljük még ki a tőzeg kiaknázásához használt 8 LE teljesítményü Dobbery-féle préssel bíró gépet. Mindez egy jól müködő agárnagyüzemet mutat. (UJVÁRY 1914:321-322)

Ezek után talán már nem is tủnik meglepetésnek, hogy Hunyady gróf hamar felismerte a fürdőélet fejlesztésében rejlő jövedelemszerzés lehetőségét. A kéthelyi uradalom északi részén, a tó partján feküdt Balatonberény, ahol a grófnak 2830, mellette Balatonújlakon 459 holdas birtoka volt. (GAZDACÍMTÁR 1893) Itt indította meg a turisztikai célú fejlesztéseit. Kétségtelen, hogy a Balaton parti településeken, így Berényben is az 1880-as évek körül nyaranta néhány fürdőző már megjelent, akik föleg Budapestről, Nagykanizsáról és Székesfehérvárról érkeztek. A balatoni nagybirtokosok közül Hunyady Imre volt az első, aki 1881-82-ben kényelmes és ízléses nyaralót épített. Ez a földesúri nyaraló Balatonberényben, a parttól mintegy 150 méterre, de már a vasúttól délre húzódó löszös dombhátra került. Szakirodalmi adatok szerint ezt évet tekinthetjük a berényi fürdőhely alapító évének. (LUKÁCS 1942:287) Hunyady Imre ugyanakkor jó példát is mutatott: családjával, népes rokonságával hosszú éveken át ott töltötte a nyarakat. A nyaraló mellé parkot alakítottak ki, amelynek nyomait még ma is lehet látni.

Hunyady gróf nemcsak nyaralót épített, hanem kezdeményezője volt a gőzhajózásnak is. A nyaralójától északi irányban, át a vasúton, egy nyílegyenes út vezetett le a partra, ahol egy hosszú mólót épített azért, hogy saját tulajdonú kis gőzhajója kiköthessen. Ezen a gőzhajón nemcsak ő és családja, hanem a fürdővendégek is tehettek kirándulásokat. Abban az időben félórás hajókázással Keszthelyt vagy Szigligetet el lehetett érni, de egy egyórás úttal már a badacsonyi bortermelők borait is fogyaszthatták a vendégek. Hunyady gróf gőzhajója a későbbiekben a Balatontavi Gőzhajózási Részvénytársaság tulajdonába került, s Rohan néven teljesített szolgálatot. Majd amikor a társaság tulajdonában 1900-ban már ott volt a Helen, a Kelén és a Helka, akkor a Halászatnak adták el a hajót. A balatonberényi gőzhajókikötőt a későbbiekben elhordták, de a helye az 1940-es években még látható volt. (LUKÁCS 1942:287) A fejlesztések harmadik lépése a balatonberényi fürdőtelep kiépítése volt. Ennek érdekében a gróf a saját nyaralója melletti dombon lévő földeket parcelláztatta, hogy ott villák, nyaralók épülhessenek. Mindez egyáltalán nem utal a korban meglévő „Kastgeist” szellemiségére: a földesúri nyaraló és a falu Fő utcája közti kelet-nyugat irányú „utcában” alig egy évtized alatt már több villát felépítettek: 1896-ban már bizonyíthatóan állt hat villa. (SZAPLONCZAY 1896:14) Az alábbi Bolemann-térképen is jól látható, hogy 1900-ra már előrehaladt a villaépítés. 
1. ábra. B-Berény nyaraló telep.

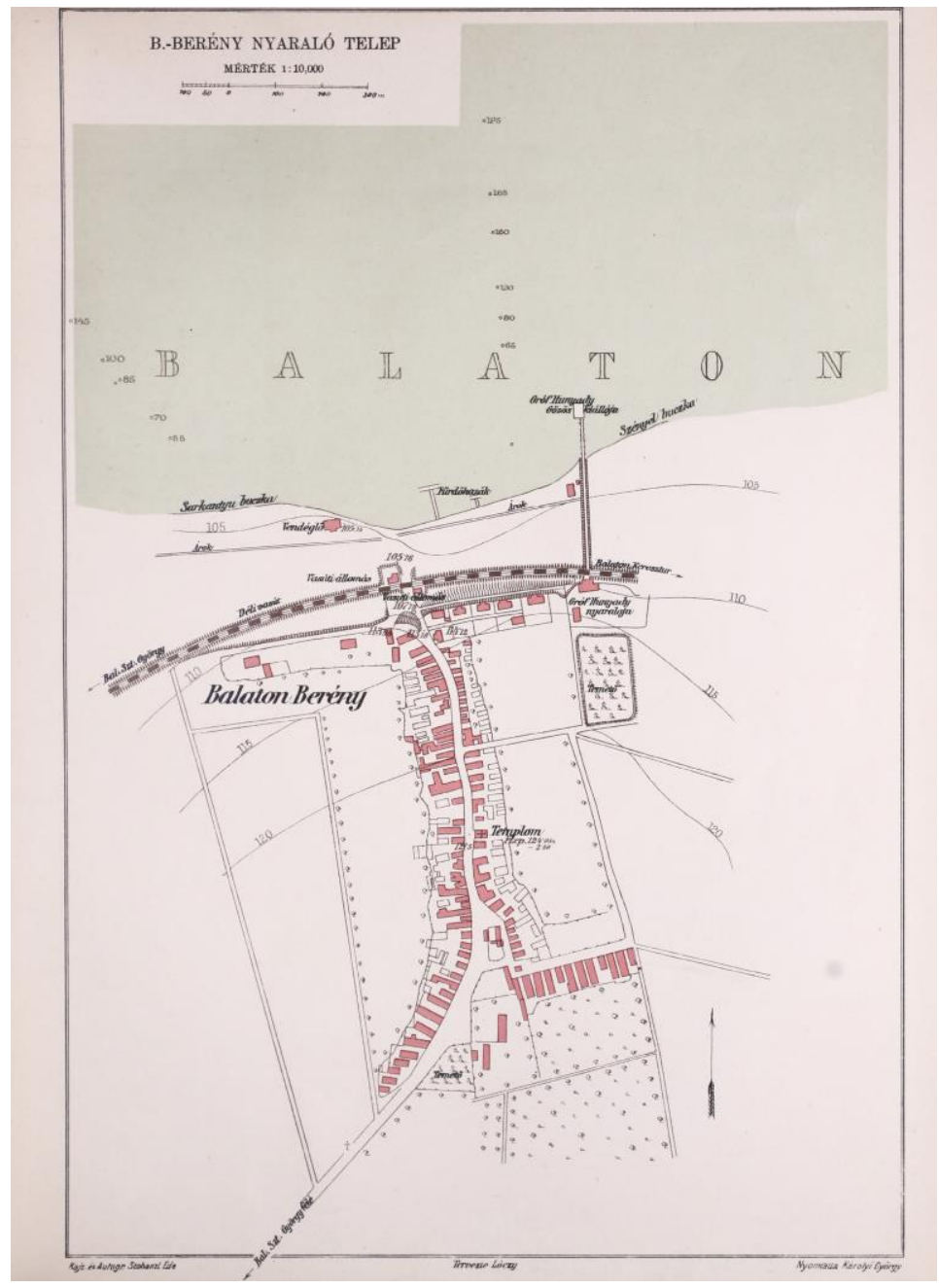

Forrás: BOLEMANN 1900.

A nyaralóépületek iránti kereslet gyorsan nőtt, ami további fejlesztéseket igényelt. Az 1890-es években építették föl a Magyar Tenger Szállodát, amely a part és a vasút közti területre került (helyén a később OKISZ-üdülö, ma Beach-Hotel van).

\section{2. ábra. A Balaton parti Magyar Tenger Szálloda}

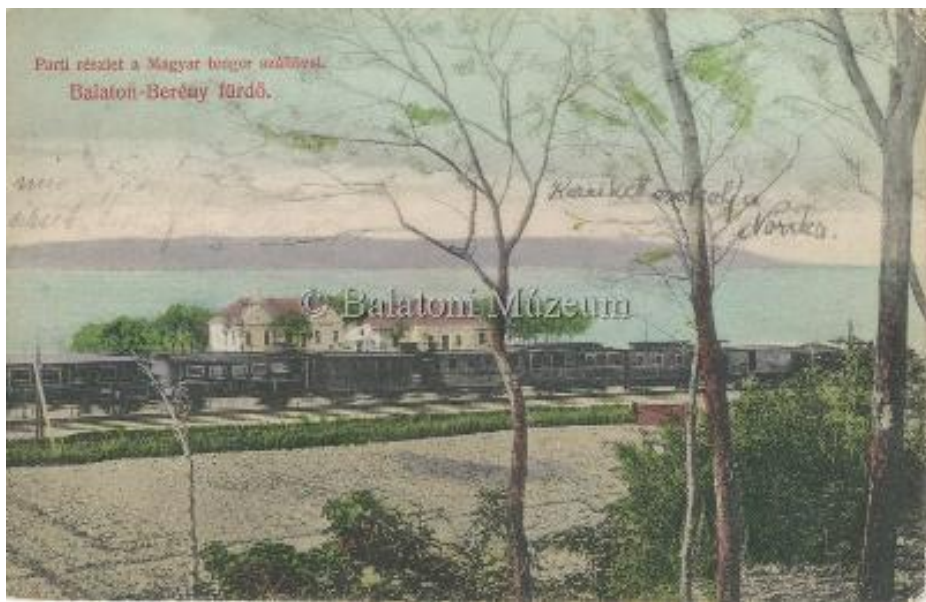

Forrás: https://mandadb.hu/tetel/51223/Balatonbereny_furdo 
A szállodában kilenc szoba és három vendéglői helyiség volt. A szálloda egy korabeli, kicsit fricskázó sajtócikk szerint egy gabonamagtárszerü épület volt, s közvetlenül a vízparton állt, elötte csónakkal is ki lehetett kötni. Hogy csökkentsék a természeti veszélyeket, a partszegély homokos földjét igyekezett nyár- és füzfaültetéssel megkötni. A szálloda és a falu közötti terület jó néhány évig még libalegelő (ahogyan akkor mondták: zsibagyöp vagy zsibalegelő) maradt. (BV 1902. 08. 10.)

E korai időszakban egyre többen keresték föl Balatonberény nyaralóit. Szerencsés módon fennmaradt egy fürdővendég-lista az 1888. év júliusáról, amely bepillantást enged abba, hogy a „hőskorban” kik is látogatták Berényt. (MM. Adattár, A-254, EÖRY 2008:22) Természetesen véletlenül sem gondoljuk, hogy egyetlen egy forrás alapján általánosítható képet tudunk a kérdésről alkotni, mivel azonban újabb, hasonló jellegü források előfordulását nem várhatjuk, mindenképpen érdemes kicsit a mélyére nézni. A lista 72 fürdővendéget sorol fel, akik esetében sokszor ott szerepel, hogy az illető a családjával volt jelen, ami arra enged következtetni, hogy vélelmezhetőn 250-300 vendég is megfordulhatott egy hónap alatt. A nyilvántartás tartalmazza azt is, honnan jöttek a vendégek. Egészében véve azt mondhatjuk, hogy a Balatonberénytől a Somogy megyei területek felé rajzolt 30-40 km félkörből (Kéthely, Pusztakovácsi, Gomba, Boronka, Vörs, Balatonszentgyörgy, Csákány, Nikla, Nemesdéd stb.) érkezett a vendégek 70\%a, legtöbben (15-en) a 20 km-re lévő Marcaliból, a járási székhelyröl jöttek. Az ezen kívül eső Somogy megyei területeket vizsgálva, jöttek még fürdőzők Kaposvárról, Csurgóról, Nagybajomból is. A közeli Zala megyéböl találunk öt keszthelyi és négy nagykanizsai vendéget. De érkeztek távolabbi helyekről is: a vasutat kihasználva tíz budapesti fürdőző is megjelent Berényben, de még hódmezővásárhelyiek, székesfehérváriak és esztergomiak is előfordultak, nem is beszélve a négy pécsi vendégröl. Érdekes módon külföldiek is jöttek: a jövevények között négy hölgyet is találunk, akik Innsbruckból, Párizsból, Pólából és Bécsből érkeztek, vélelmezhetően a grófi család vendégei lehettek.

A forrás alapján tudunk valamit mondani a fürdővendégek foglalkozására és származására is. Ez alapján több csoportot lehet elkülöníteni. Az egyik az elit kör: Hunyady Imre gróf és családja mellett a vélelmezett külföldi vendégeik egy zárt csoportot mutatnak. Nagy számban voltak jelen a környék köznemességének tagjai, a sokszor csak párszáz holddal rendelkező tisztviselők, hivatali állások betöltői, vagy egyszerüen csak földbirtokosok. E csoportból emeljük ki Kacskovics Lajos szolgabírót, a Boronkán jelentős uradalommal rendelkező Kund Jenőt, a pusztakovácsi Bogyay Lajost, avagy éppen a Veszprém megyei perkátai birtokos Bittó család egy tagját. (GAZDACÍMTÁR 1893, KAPOSI 2019) A legtöbben azonban - s ez mutatja az idők változását - egyértelmüen polgári fejlődéshez köthető foglalkozással bírtak. A listán nagy számban szerepelnek orvosok, állatorvosok, ügyvédek, gyógyszerészek, kereskedők, de találunk köztük főgimnáziumi tanárt, állomásfönököt, joghallgatót, albírót is. (MM Adattár, A254, EÖRY 2008:22) Mindez arra utal, hogy a kiegyezés után eltelt két évtizedben a polgári fejlödés során egyre erősebb lett az a társadalmi réteg, amely már megengedhette magának a nem túlságosan magas színvonalú nyári balatoni nyaralást.

A vendégforgalom fellendüléséhez nagyban hozzájárult, hogy a vasúti fejlesztések révén Balatonberény könnyen elérhetővé vált. A már említett, 1861-től működő Déli Vasút vonala lehetőséget adott a budapesti, a székesfehérvári, avagy a másik irányból a nagykanizsai polgároknak a település elérésére. Berénytől pár km-re ott volt a nagy vasúti elosztóközpont, Balatonszentgyörgy, ahonnan 1888 szeptembere óta egy szárnyvonalon a $10 \mathrm{~km}$-re fekvö Keszthely is elérhetővé vált. (KÉPVISELÖHÁZI IROMÁNYOK 1887. 1. 1-40.) A Déli Vasút Balatonberényben is kialakított egy vasútállomást. De legalább ennyire fontos volt a délre eső területek vasúti elérése. A 19. század utolsó két évtizedében egyre több helyi érdekü vasút (vicinális) épült. Somogy megyében a vicinálisok kezdeményezői az áruforgalom növelése érdekében a legtöbbször helyi nagybirtokosok voltak. Ez térségünkben is így történt. 1889-ben 
a nyugat-somogyi régió két nagybirtokosa, gróf Hunyady Imre és a marcali uradalom tulajdonosa, gróf Széchényi Gyula kapott engedélyt a Szentgyörgy - Berény - Keresztúr Kéthely - Marcali - Somogyszob vasút megépítésére, hozzájuk csatlakozott a későbbiekben gróf Festetics Pál, a böhönyei uradalom tulajdonosa is, de emellett támogatták kisebb polgári közösségek is az építést. Az elsődleges tervekben persze a teherszállítás szerepelt, de hamar fel lehetett ismerni a személyszállítás, $\mathrm{s}$ ezen keresztül a Balaton parti fürdők elérésének fontosságát is. A Somogyszob - Szentgyörgy vasútvonal Keresztúrnál érte el a Déli Vasút balatoni vonalát, majd belevezették a fővonalba, de Szentgyörgyig a saját vasúti szerelvényeit használta a Társaság. A Balatonszentgyörgy - Somogyszob vonalat 1893-ban adták át. (ERDÖSI 1982:186-190)

A nagy társadalmi kereslet révén Berényben a part menti területek felparcellázása után egyre többen vásároltak telket, s így gyors ütemben elindult a fürdőtelep kiépülése. Az 1910-es évekre már három szálloda volt Balatonberényben, összesen 120 kiadó szobával, s mellettük egyre nagyobb méretű nyaralókat építettek. A tulajdonosok között találunk zalaegerszegi, szombathelyi, nagykanizsai polgárokat, amely jól mutatja, hogy Berény viszonylagos közelsége is sokat jelentett a beruházóknak. A gróf példáján felbuzdulva további nyaralókat építtettek: a mai Baranya Megyei Önkormányzat Gyermeküdülőjét, a Marzsó-féle villát, a Karay-villát, a Jalsoveczky-villát és Somogyi uraság villáját, amely később az első óvodának adott helyet. Az Armuth-telep folytatásában épült a marcali Roszmanith Antal bőrgyáros villája és Páli Lajos vendéglős három egyforma villája.

\section{3. ábra. Páli Lajos vendéglős villáiból kettő egy korabeli képeslapon.}

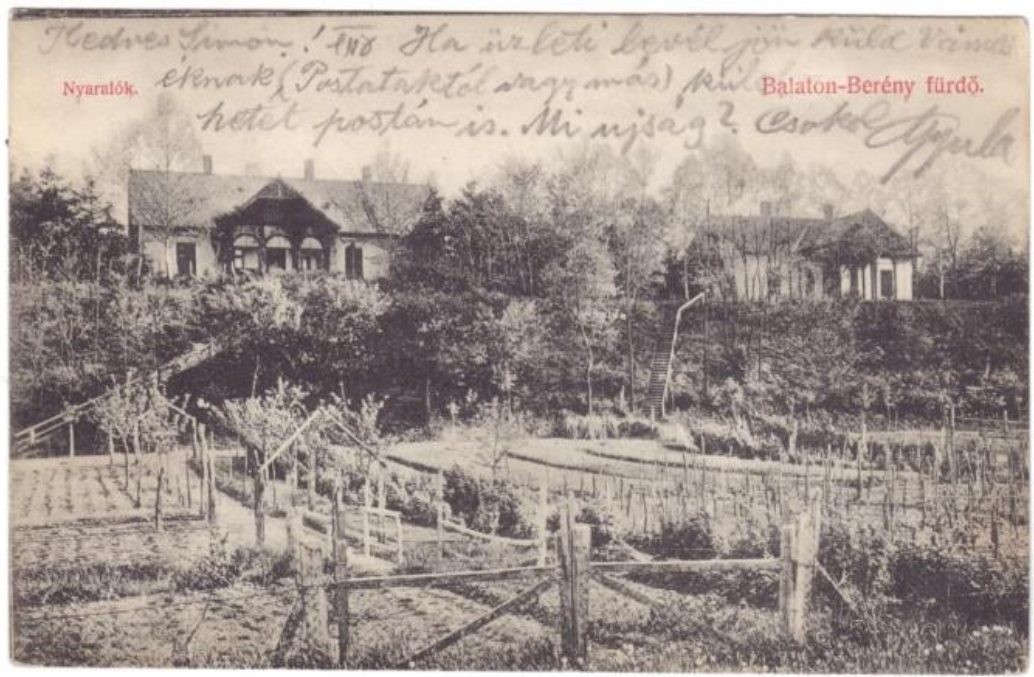

Forrás: MM. Tdgy. 2020.38.3.

Így a falu vasút melletti nyugati része villaszerűen gyorsan beépült. Ebben az időben épült a későbbi Mátravidéke KTSZ üdülője, amely ugyancsak szállodai célt szolgált. (RIGÓ 2018:9) Még nagyobb földesurak is villaépítésbe fogtak. (Tegyük hozzá, hogy ez nem volt ritka, Balatonboglár esetében például az egyik meghatározó nyaralóépület sokáig a gróf Somssichvilla volt.) Így például a szabási földesúr, a híres szakképzett gazda Somogyi Gyula, aki 1891től a ma már Nagykanizsához tartozó palini uradalom egy részét megvette, Balatonberényben is telekhez jutott, ahol később a fia nyaralót épített. A földesúr palini kastélyában tartották 1894ben a berényi fürdőtelep kiépítésének értekezletét. (GÖCZE 2014:686-688, TARNÓCZKY 2013:143) Tegyük még hozzá, hogy a fentieken túl a Magyar Tenger Szállodától keletre lévő partszakaszon a helyiek igen sok fürdőházat (fürdőkabint) építettek, amelyeket viszonylag olcsón adtak bérbe a fürdőzőknek. 
Kiemelkedett a beruházások sorából a nagykanizsai Armuth Náthán (1857-1942) által épített szálloda és fürdőtelep. Armuth alapvetően gyarmatáru forgalmazással foglalkozó nagykereskedő volt, akinek nagykanizsai cégét 1882-ban jegyezték be. Ö volt a liesingi sörgyár kanizsai képviselője és forgalmazója is, de számos más vállalkozásban is érdekelt volt. A tehetős kereskedőnek Nagykanizsa központjában volt feleségével, Kohn Herminával közösen vásárolt háza, ennek udvarán alakította ki a liesingi sörcsarnokot. (KUNICS 2009:272) A Hunyady József gróffal kötött megállapodás alapján nemcsak a balatonberényi szállodában, hanem Nagykanizsa központjában is forgalmazta a gróf Baglas hegyi borait.

Armuth 1903-ban kezdte kiépíteni balatonberényi fürdőtelepét, amit 1906. június 18-án adtak át. A telep kiépítésének költsége mintegy 80-90 ezer korona volt. A telep, amely három épületből állt, a vasútállomással szemben fekvő, a vágányoktól délre, az állomástól nyugatra eső üres telekre került. Az épületekben 105 szoba, egy nagy étterem, egy kávéház, s minden egyéb szükséges mellékhelyiség megtalálható volt.

\section{4. ábra. Az Armuth-nagyszálloda Balatonberényben}

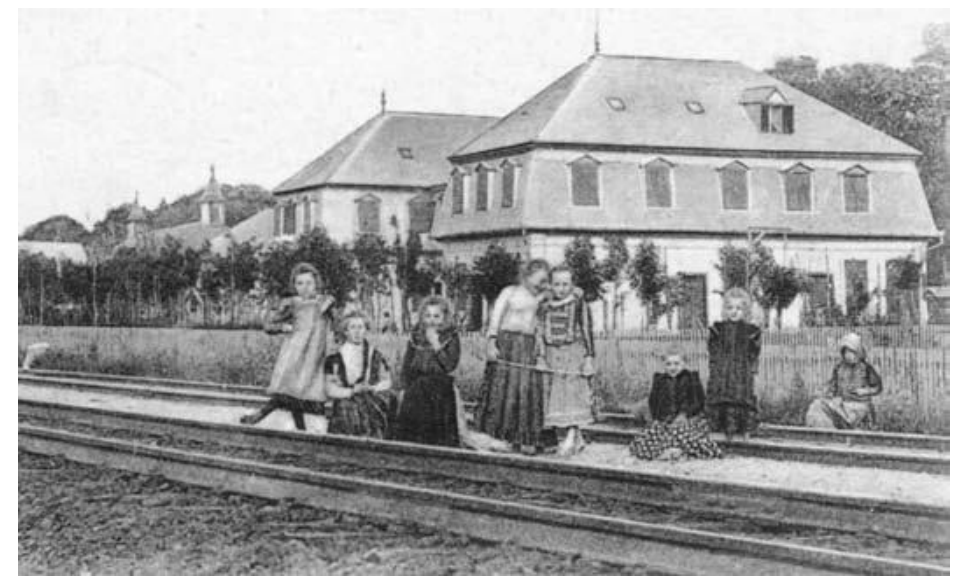

Forrás: Tarnóczky 2013:648

Korabeli sajtóbeszámoló szerint a szobák nagyok, szárazak és világosak voltak, ízléses bútorozottsággal, s minden lehető kényelemmel ellátva. Az épület faszerkezetü volt, a szobákat is deszkafal választotta el egymástól. (BV 1906. 08. 12.) Az esti világítást acetilén-lámpákkal oldották meg. Mint általában a megnyitók, ez is nagy tömeg megvendégelésével járt, a díszes vendégsereg pazar lakomájáról Lengyel József vendéglős gondoskodott. (BV 1906. 06. 24.)

\section{5. ábra. Egy korabeli reklám az Armuth-szállodáról (1911)}

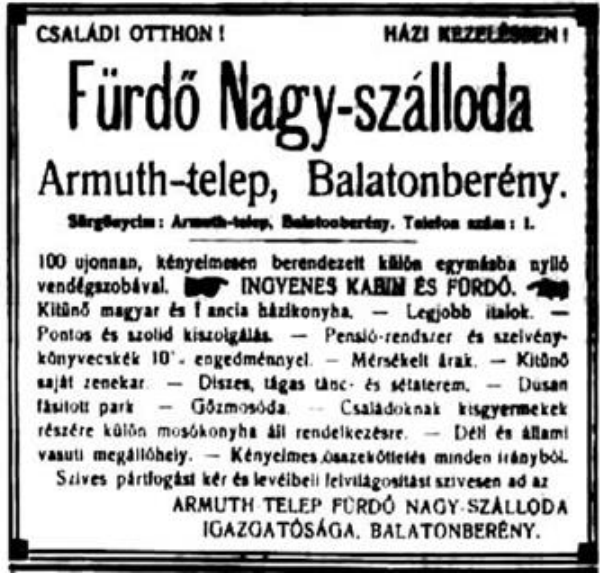

Forrás: TARNÓCZKY 2013:648 
Tipikus volt a korabeli gazdasági életben, hogy a hasznosítás és a tulajdon elvált egymástól, vagyis a szállodát bérbe adva müködtették. (A szálloda nagy épületét a második világháború után elbontották, elhordták, kisebb részeit Nagykanizsa város gyermeküdülöjeként hasznosították.) Amúgy a szállodavezető mindent megtette a forgalom bővítésére, így például széles volt az ételkínálat is. Egy 1906. évi vendég beszámolója szerint a meleg ételeken kívül lehetett ott kapni sajtot, vajat, fokhagymát, szalámit, kvarglit, zellert, tormás szafaládét, csirkét, tengeri békát, sőt még a feledékeny turistának úszónadrágot is árultak. Ez összevetve a korabeli keszthelyi nagyszálló kínálatával, jóval magasabb szintünek mondható. (BV 1906. 08. 12.)

\section{6. ábra. Az Armuth-telep épületei Balatonberényben (1908)}

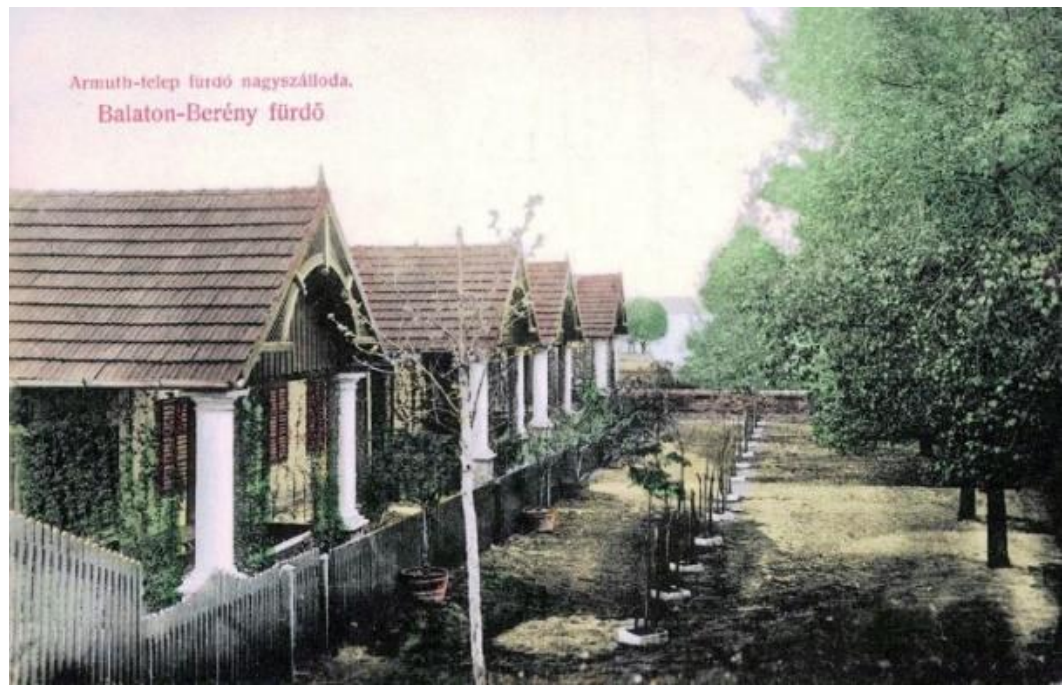

Forrás: https://mandadb.hu/tetel/509220/Armuthtelep

Egy arisztokrata család mindig mintaadó volt a helyi lakosság számára, így nem véletlen, hogy Balatonberényben a századforduló idején nagyon gyorsan kiépült a fürdőrendszer. A korabeli fürdőismertetők és a sajtóhírek alapján azt mondhatjuk, hogy a századforduló utáni években már évi 1500-2000 vendég kereste föl Balatonberényt, de a kirándulók száma a 3000-4000 föt is elérte. (SZAPLONCZAY-VAJTHÓ 1907:44) A helyi parasztok és polgárok szerény hajlékaikat vendégek fogadására is alkalmas épületekké kezdte átalakítani. A füstös konyhák és a Fö útra néző tiszta szobák ideje kezdett lejárni, s egyre több vendéget fogadtak a magánházakban. Az 1900-as évek elején már mintegy 200 szobát adtak bérbe a helyiek. Lehetőség volt szobák bérlésére, de kiadtak teljes házakat is, havi 100-150 koronáért, konyhával, tüzifával stb. Az ilyen lakásbérletekhez a Balatonban egy kényelmes fürdőkabin is járt. Ennek jelentős hatása volt a falu fejlődésére. Hamar, már 1895-ben elkezdődött a Balatonberényi Fürdőegylet megszervezése, amely végül is 1899-ben alakult meg. (BÖSZE 1989:218) Az egyesület gondoskodott a köztisztaság fenntartásáról, a fásításról, az ülőpadokról és a vendégek szórakoztatásáról is. (SZAPLONCZAY 1914:21) 1905-ben a falusi közösség beszerzett több öntözőgépet, amivel napi kétszer-háromszor fellocsolták a balatoni finom homok miatt állandóan igen poros utcákat. (BV 1905. 07. 30.) A szolgáltatások az évek során egyre szélesedtek. 1910-ben például egy nagykanizsai vállalkozó, Lőwy Sándorné ,okleveles arcmasseure" Balatonberényben - követve vendégeit - fürdőhelyi arcápoló szalont nyitott. (TARNÓCZKY 2013:1106-1107)

A földesúri uradalomnak nagyon nagy szerepe volt a fürdőzők ellátásában. Ebben a korszakban a balatoni fürdőhelyek, vagyis sok száz ember ellátása két forrásból valósulhatott meg. Egyrészt a földesúri majorság termelvényei, nyersanyagai szolgálták ki a vendégeket, vagyis a liszt, a hús, a tej és tejtermékek, a kertészeti termékek stb. mind a majorságból származtak, további 
üzleti előnyöket biztosítva a földesúrnak. A szállodákban, vendéglőkben elsődlegesen a nagykanizsai sörgyár termékeit, illetve a kéthelyi uradalom szőlöhegyein termelt jó minőségü borokat kínálták, nem is beszélve az egyéb szeszes italokról. (A sörgyárhoz lásd: KAPOSI 2014:162-165) A tehetős látogatók - a hazai polgári szokásoknak megfelelően - föleg marhahúst fogyasztottak, a szegényebb rétegnek a disznóhús jutott. A településen müködött egy mészárszék is, vagyis a napi frisshús-ellátás biztosított volt. Másrészt az is megfigyelhető, hogy a községben is egyre több bolt jött létre, bár kétségtelen, hogy a polgári-paraszti házakat bérlöket élelmi cikkekkel elsődlegesen a lakosság látta el. Mivel szabadpiaci rendszer volt, ezért lassan a polgári-paraszti helyi termelés is éledezett, ami föleg a magán vendéglátás esetében olcsó zöldség- és gyümölcskínálatban és szeszes italok forgalmazásában jelent meg. (SZAPLONCZAY-VAJTHÓ 1907:45) 1896. évi forrásunk arról tudósít, hogy a közeli Marcaliból vagy Keszthelyről is beszerezhető volt az élelmiszer egy része. (SZAPLONCZAY 1896. 14.) Berényben, de a mellette lévő településeken is egyre több ház épült a szőlőben, amely nemcsak a szőlőművelést fokozta, hanem a fürdővendégek kiszolgálásának lehetőségét is bővítette. (LÓCZY 1978:332) Emeljük ki a Balatonkeresztúr melletti Festetics-birtok átalakítását, ahol a filoxéra-járvány miatt tönkrement (döntően zalai) szőlőművelőknek kimért parcellákon jelentős müvelés indult meg, amely elvezetett a telkesítést irányító Széchényi Imre feleségéről, Andrássy Máriáról elnevezve a balatonmáriai partvidék fejlődéséhez. (HUSZÁR 2016:14-16)

A turizmus e hőskorában az ideérkező vendégek, főleg a más életvilághoz szokott városi polgárok egyszerre érzékelhették a falusi múlt, a jelen és az esetleges jövő képét. Kétségkívül hatalmas különbség volt a korábbi léthelyzethez képest abban, hogy a falu Balaton melletti területein szállodák, vendéglők, szórakozóhelyek, fürdőkabinok épültek, s ezek kiszolgálása, ellátása, a fürdőélet müködtetése az újszerüséget hozta. De a falu délre eső részein, a fürdőteleptől párszáz méterre, a régi faluban még mindig a hagyományos élet uralkodott. Érdekes ennek az ellentmondásnak a megjelenése egy 1906. évi vendég leírásában, amely szerint igen elborzasztó volt Berényben, a falu egyik kiadott házában lakva, hogy hajnali négy óra felé a falusi csikós kurjongatására a parasztok kieresztették a Fő utcára a lovakat, amelyek kivágtattak a falusi legelöre. Fél órával később jött a marhacsorda, amelyhez legalább nem kurjongattak. Valamivel később hajtották a sertéseket a legelöre, s ehhez képest a mintegy 1100 liba gágogása már nem okozott semmiféle meglepetést az ember nyaralása során. És ennek ellenére 1300 fürdővendég volt ekkor a faluban. Ezek után már nem véletlen a következtetés, miszerint „Én dacára annak - hogy addig a lábam ebbe a községbe nem teszem, míg rendes világitás, öntözés, fásitás, pocsolyák-, utak rendezése nem lesz keresztülvive - nem itélem el az idejövö fürdövendégeket, mert velem együtt ők is édes hazánkért szenvednek és megtakaritott filléreiket nem egy rendezett osztrák fürdőben, hanem egy rendezetlen, de reményekre jogosult magyar fürdöben költik el." (BV 1906. 08. 19.)

\section{A balatonszemesi fejlesztések}

Mint már említettük, a Hunyady grófoknak tekintélyes méretü faluszemesi (balatonszemesi) birtokai is voltak. A szemesi uradalom kiterjedt a mellette lévő szárszói és a szóládi földekre is, ezek 1893-ban összesen 11.200, 1911-ben pedig 11.169 holdat tettek ki. (GAZDACÍMTÁR 1893, 1911)

A berényi eset után nem tekinthető véletlennek, hogy a szemesi fürdőélet kialakulásban is a grófi családnak volt meghatározó szerepe. Egyrészt a faluban ott volt a család kényelmes úriháza, „foúri kényelemmel berendezett kastélyépület”, amely kiváló lehetőséget adott a nyarak eltöltésére. (GYULAY 1911. 3. 186) A 12 köríves tornácos, L-alakú, barokk stílusban épült kúria ma is megvan, 1952-től a kastélyépületet iskolai funkciókra hasznosították, ma a Reich Károly Általános Iskola és Alapfokú Müvészeti Iskola müködik benne. A grófi épületnek 
100 éves múlttal bíró parkja volt. A földesúri rezidencia hajdan persze nem nyaralóépületnek épült, hanem majorsági központnak, ezért mellette ott voltak a gazdaságot kiszolgáló egyéb építmények is: magtárak, cselédházak, istállók, s volt egy 70 LE teljesítményü gőzmalom is. (GYULAY 1911:4, 1911:254)

\section{7. ábra. A balatonszemesi Hunyady-féle úrilak 1914 előtt}

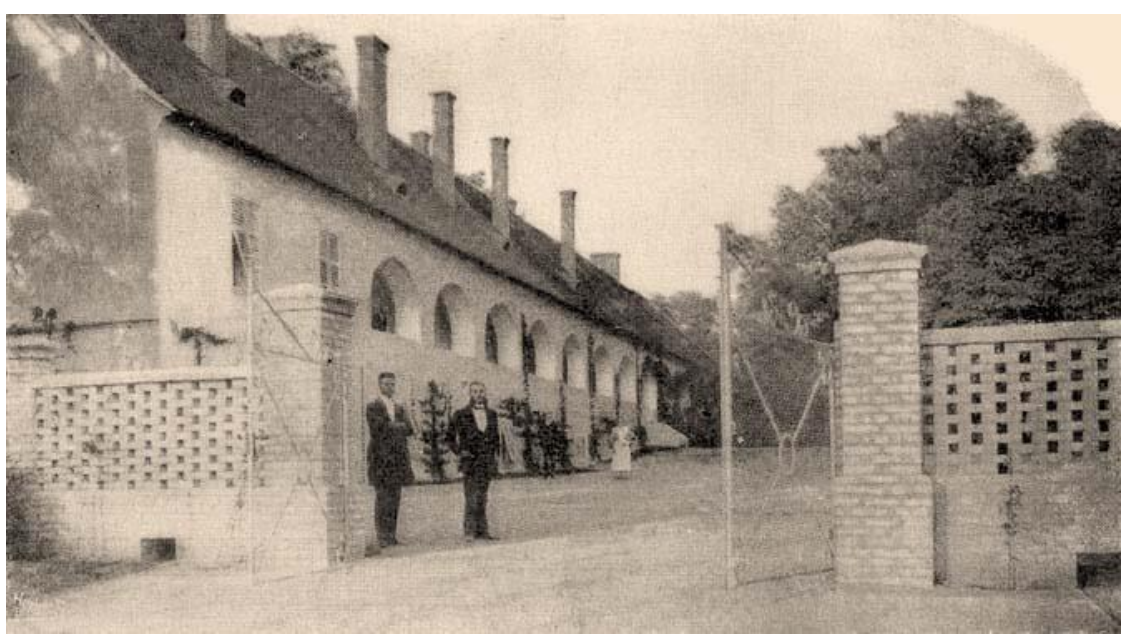

Forrás: REISZIG 1914:42-43

A Sári pusztai kastély mellett a grófok tartósan soha nem laktak Szemesen, de a 19. század végén egyre többször jelentek meg a birtokukon. Fontos rögzíteni, hogy a korabeli kataszteri térkép tanúsága szerint a szemesi Balaton-part 90-95\%-ban a gróf tulajdonában volt, a falusi közösségnek csak nagyon kis saját területe volt, föleg ott, ahol az észak-déli fekvésü falu vonala a tóra kifutott. (https://mapire.eu/hu/map/cadastral) A halászat a gróf kizárólagos tulajdonában volt. (PESTY 2001:295)

A szemesi uradalom településein a lakosság hagyományosan mezőgazdasági termeléssel és halászattal foglalkozott. Szemes nagy előnyei közé tartozott, hogy viszonylag jól megközelíthető volt távolabbi utazók számára is. Egyrészt a Budáról Nagykanizsa felé vezető, a Balaton déli partján futó régi országút áthaladt falun. Ez az út egyben postaút is volt. Szemesen a 18. század végétől 1861-ig müködött posta-lóváltóállomás, erre az első adat 1792böl származik. Az ehhez szükséges épület a gróf tulajdonában volt. A postautat a 19. században sokszor javították, kövezték, fásították stb. Szemes postaközpont volt, innen hordták szét a környék birtokosai a küldeményeket. Az első postaállomás a kastélyban volt, később a mai postamúzeum melletti épületben; míg a mai postamúzeum a grófi család egyik hajdani épületében kapott helyett. (REÖTHY 1989)

Másrészt nagy lehetőséget adott, hogy az 1861-ben átadott vasút Szemesen áthaladt. Eleinte Szemes csak egy ún. forgalmi kitérő volt, de 1897-ben már Szemes is kapott állomást, vagyis a falu megközelíthetösége, nem is részletezve az áruszállítás lehetőségét, látványosan javult. (REÖTHY 1990/b:184.) Megjelentek az első fürdővendégek, eleinte föleg Székesfehérvár polgárai látogatták. A forgalom növekedése az 1890-es évek közepén indult meg. Tény az is, hogy az 1890-es években már a kelet-balatoni térségében is egyre több változás figyelhető meg, így például a szemesi uradalom mellett Balatonföldváron gróf Széchényi Imre 1894-ben elkezdte kiépíteni a fürdőtelepet. A minta adott volt: a szemesi fejlesztések egy évvel később, 1895-ben indultak meg, amiben meghatározó szerepe volt gróf Hunyady Imrének és feleségének. 
A munkálatok a Balaton partján egy nagyobb grófi telek parcellázásával indult meg. Első lépcsőben 110 telket mértek ki, amelynek irányításában a grófnő, Győry Teréz személyesen is részt vett. A telkesítést az is motiválta, hogy közben a Déli Vasút Társaság már építette a mellette lévő állomásépületet. A fürdőtelep két részből állt. A sínek és a vízpart közötti alsó telepen többnyire 600-800 négyszögöles telkeket alakítottak ki; hasonló méretü telkek képezték a mai Bagolyvár utcára, mint fötengelyre épült felső telepet is, amit a későbbiekben déli irányban kiterjesztettek. 1898-1902 között további tereprendezési munkálatokat végeztek egészen az öszödi határig, ezzel párhuzamosan pedig Pausar Károly uradalmi erdész irányításával a rézsü és a vasút közötti területet fenyőkkel és lombos fákkal, parkosították. (STIRLING 1990:231) A parcellákat gyorsan értékesítették, amihez az is hozzájárult, hogy az alsó telep telkeit Hunyady gróf négyszögölenként kezdetben egy, majd néhány év múlva két koronáért adta, míg a felső telepen egy négyszögöl három koronába került; ugyanakkor más balatoni településeken akár 20-25 koronát is elkértek egy négyszögölért. (SH 1911. 09. 08.)

\section{8. ábra. Balatonszemes fürdőtérképe (1931)}

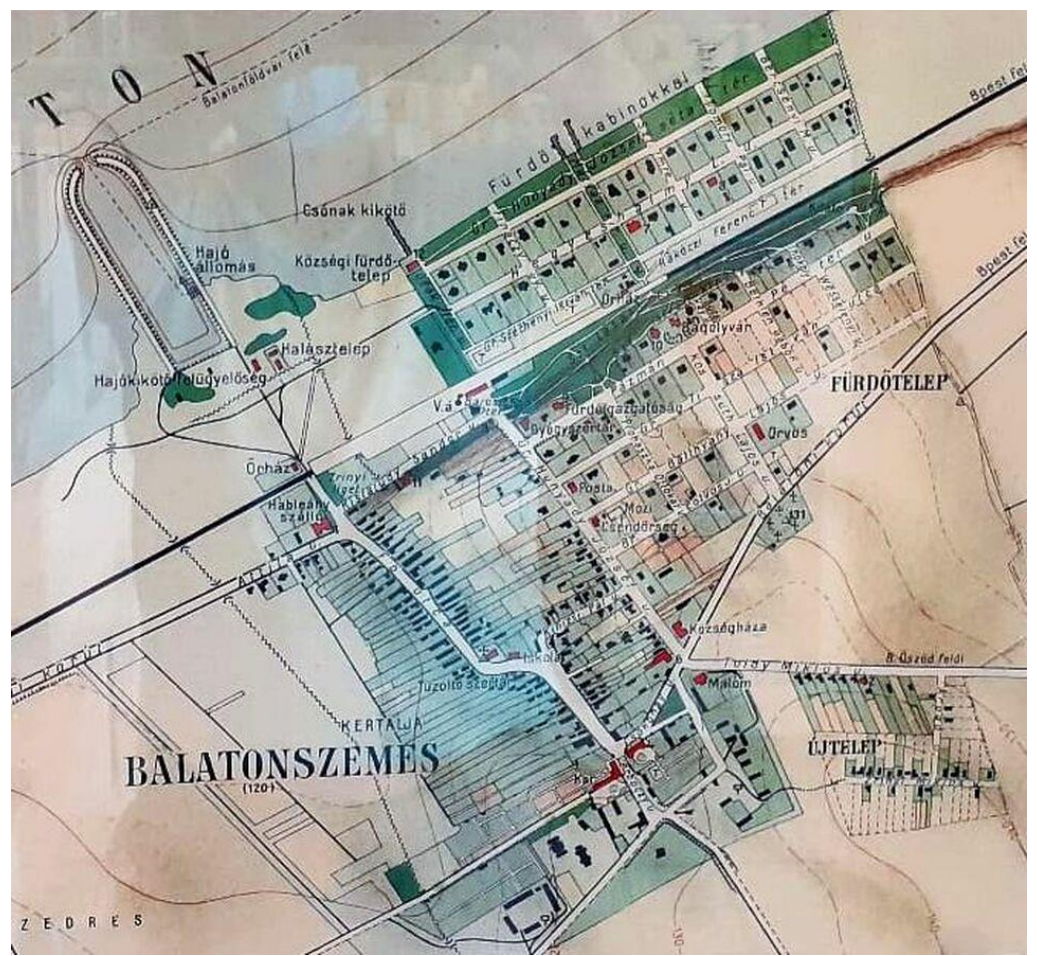

Forrás: Magyar fürdőtérképek 9. maps.hungaricana.hu/hu/HTITerkeptar/34170

Akárcsak Balatonberényben, itt is hamar megkezdődtek a villaépítések. Az elsőt Vajdits Alajos ezredorvos építette 1898-ban a híres Roman Morandini nagykanizsai müépítész tervei alapján, romantikus stílusban. (Morandinihez lásd: KUNICS 2009) Az építkezés az egykori Bolondvár helyén történt. (A később Bagolyvár nevet viselő villa némileg átalakított formában a későbbiekben vállalati üdülő lett, egy része ma is áll.) 1900-ban további három nyaraló épült. 1901-ben épült meg az alsó telep első villája. E ház első tulajdonosa Huber Lajos volt, amely a későbbiekben Raffay Sándor evangélikus püspöké, majd pedig Eötvös Károlyé, a tiszaeszlári per híressé vált védöügyvédjéé lett, aki a hagyomány szerint ebben a házban írta "Balatoni utazás" címü nagy sikerü könyvét. Eötvös 1908-1912 között Balatonszemesen lakott. (BEÖTHY 1979:41, STIRLING 1990) A korabeli telkek vásárlásával ekkor még nem járt együtt a vízjog élvezete is, ezt Hunyady gróf fenntartotta magának, így kabinállítás fejében a telektulajdonosnak évi 4 koronát kellett fizetnie. A kabinállítás költségei rövidesen rohamosan emelkedni kezdtek és néhány éven belül elérték a 40 koronát. A telektulajdonosok ez idő tájt 
évi 20 korona tagdíjat (ma üdülöhelyi díjnak mondanánk) fizettek az uradalomnak. Ebböl a pénzböl meg tudták oldani a közterületek és a parkok karbantartását és fenntartását. (STIRLING 1990:232)

A tulajdonos grófi család alaposan megszürte a telekvásárlók körét. Szemben Boglár és Siófok mintájával, itt a zsidókat gyakorlatilag kizárták a vásárlók közül. Hunyady Imre és fia, József gróf Szemes nyaralótelepét a hazai polgári közép- és úri rétegeknek, értelmiségieknek akarta biztosítani, ennek megfelelően értékesítették a telkeket. De még a faluban bérelt házak esetében is lekérdezték a jövevények származását. Ez az őskonzervatív magatartás már messze nem felelt meg a társadalmi elvárásoknak, de nem is verték nagydobra, csupán gyakorolták. (STIRLING 1990:234-235)

Lassan nőtt a szemesi vendégforgalom is. Már 1900-ban azt írták a településröl, hogy „,...a faluban elég tiszta és elég kényelmes szobák találhatók”. (BOLEMANN 1900. alapján) Volt mit fejleszteni, mert a falu infrastruktúrája elég elmaradott volt a 19. század végén. A Balatonhoz érkező vendégek a vonatról leszállva romantikus körülmények közé kerültek: a szemesi fürdővendégeket a vasútról ökrös szekerekkel szállították a faluba. A vendégek ládákban hozták magukkal az otthoni ágynemüt, a konyhafelszerelést, az élelmiszert, a füszert stb., mert ezek megvásárlására kezdetben nem nagyon volt esély. A szemesi gazdák viszont készpénzhez juthattak, ami egy paraszti háztartás számára mindig nagy kincs volt, ezért nyaranta a gazdák családja kiköltözött a konyhába, a fészerbe stb. (SCHOEDL 1934:20)

A grófi fürdőtelep kiépülésével párhuzamosan a község is ébredezett, s a századforduló után már több érdemi fejlesztés is megvalósult a helyiek akaratából. Ennek egyik első lépése volt, hogy a falusi közösség költségén 1905-ben elkészült a vasútvonal tó felöli oldalán, közel a parthoz, a Fő utca és a Kikötő utca találkozásánál a Hableány szálloda. A szálló hosszú ideig a szemesi társas élet egyik központja volt, mükedvelö előadásokkal, bálokkal, estélyekkel. (SCHOEDL 1934:20) A szálloda nem volt túl nagy, de mégiscsak egy többszobás nyaralóhelyröl van szó. A Hableányt bérbe adva müködtették, s elég jó forgalomnak örvendett. Hozzákapcsolódott egy vendéglő és egy mészárszék is, egy 2000 négyszögöl kiterjedésủ park, valamint számos mellékhelyiség. A bérbeadás nyilvános árlejtés mellett zajlott, a Somogy megyei Hivatalos Közlöny tette közzé, meghirdetését a körjegyző és a falubíró intézte. (SHL 1913. 02. 06.) A fejlődést mutatja, hogy Szemesen 1907-ben két szállodában 20 szoba, míg az egyéni nyaralóhelyeken még kb. 80 szoba állt rendelkezésre. (SZAPLONCZAY-VAJTHÓ 1907:35)

\section{9. ábra. A balatonszemesi Hableány szálloda (1913)}

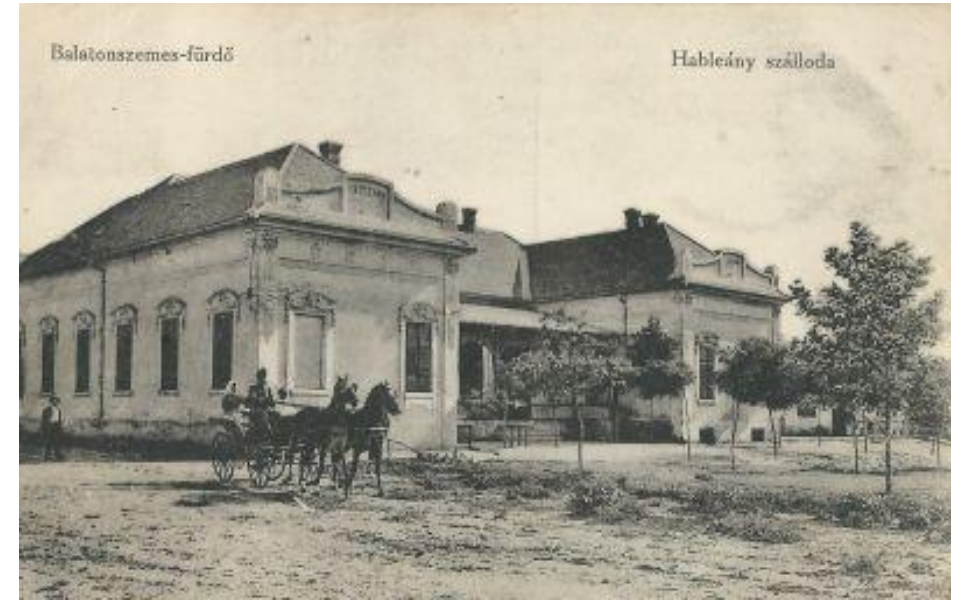

Forrás: https://mandadb.hu/tetel/514127/Hableany 
Némi vajúdás után 1908-ban Faluszemesen is megalakult a fürdőegyesület. Kezdeményezője Laurencz Ede uradalmi intéző volt, aki a villatulajdonosokkal folytatott ez irányú tárgyalásokat. A fürdőegyesület 1908. augusztus 20-án tartotta alakuló összejövetelét, mely a telep további fejlődése szempontjából is lényeges volt. (STIRLING 1990:238, BALATONSZEMESI FÜRDÖEGYESÜLET 2009:21-22) A balatoni fürdőegyesületek tagjai, vezető tisztségviselői többnyire befolyásos állami tisztviselők, államtitkárok, miniszterek voltak, akik telepük fejlesztése érdekében jelentős támogatásokat tudtak szerezni, s ezáltal fontos beruházásokat tudtak elindítani. Így került be például a szemesi fürdőegyesületbe Angyal Pál és Ladik Gusztáv, a neves jogtudósok, Térfy Béla nyugalmazott miniszter vagy Szentpétery Imre egyetemi tanár. (SVM 1908. 08. 23., BÖSZE 1997:66, BÖSZE 2002) Szemes kulturális fellendítése, az olvasókör, a mozi, a mükedvelő előadások és müsorok nagy száma is a fürdőegyesület lelkes gárdájának érdeme. Elterjedt szokássá váltak a Fürdőegyesület által szervezett, magas színvonalú hangversenyek, amelyek bevételét a fürdőtelep szépítésére használták föl. (Lásd pl. PH 1909. 07. 23., SH 1910. 07.15., AÚ 1910. 07. 29.) A szemesi olvasókör szervezte nyaranként az aratóünnepséget, amely az aratók előtti tisztelgés volt, s mai fogalmaink szerint kirakodóvásárral, büféstandokkal, egész éjjelen át tartó, lampionvilágítással biztosított táncmulatsággal végződtek. (Lásd pl. SVM 1913. 08.08.)

A társasági összejövetelek céljaira kaszinót építenek. Ehhez Hunyady gróf ingyen bocsátott rendelkezésre egy telket a Fő utcában. A kaszinó kivitelezésének ügyében a tárgyalások már 1911 tavaszán megkezdődtek. Az építkezéshez a gróf saját téglagyárából 46 ezer téglát ajándékozott, a teljes építkezés bruttó költsége mintegy 4000 korona volt, melyet a villatulajdonosok úgy adtak össze úgy, hogy kibocsátottak $40 \mathrm{db} 100$ korona címletü, évi 6\% kamatozású kötvényt. (STIRLING 1990:248) Az építkezés még ugyanebben az évben befejeződött, de végül is nem kaszinó, hanem csendőrségi épület lett.

Fontos új beruházás volt a kikötő megépítése, amivel a növekvő látogatottságú fürdőhelynek a balatoni vízi forgalomba való bekapcsolódása is megvalósulhatott. Széles társadalmi összefogás jött létre a kikötő megépítéshez. A hozzá való telket a grófi uradalom felajánlotta a kincstárnak. (KERTAI 1974:53) 1912-ben az alispán vezetésével megtörtént a közigazgatási bejárás. (PH 1912. 07.17.) A kikötő állami pénzből épült meg, de kapott a falu a kikötőhöz vezető út építésére is állami támogatást. (SVM 1912. 08.18.) Ehhez kapcsolódott az első vitorlásverseny is. 1912-ben alakult meg Szemesen a Balatoni Yacht Club. A Club, amelynek vezetésére gróf Hunyady Józsefet kérték föl. A gróf úgy tekintett működésére, hogy az nemcsak a hazai arisztokrácia egy kis részének a szórakozása lesz, hanem abból a vitorlásversenyek megszervezésével, a háttérinfrastruktúra kialakításával, a kikötőfejlesztéssel, a versenyek lebonyolításával a helyi polgárságnak is jelentős haszna származhat. 1913 nyarán megrendezték az első vitorlásversenyt. (SV 1913. 08. 25.) 1914-ben a balatoni fürdőhelyeket áttekintő leírás már arról szólt, hogy Szemesen „Az állami kikötő mólójának épitkezése folytán a hajó- és csónakközlekedés is szép fejlödésnek indult”. (V 1914. 06. 14.)

A szemesi fürdőegyesület támogatta a közmüfejlesztést is. Hunyady gróf átengedte a parkdíjszedési jogot az egyesületnek. Nagyszabású parkosítás kezdődött: az uradalmi gazdasági munkák szünetelésekor a gróf adott igaerőt a park rendezéséhez, az ott kitermelt irtásfát és a lekaszált füvet pedig átengedte az egyesületnek. (BÖSZE 1989:233) A fürdőegyesület fennállásának ötödik évében a telep olyan szépen fejlődött, hogy 1000 fürdővendéget tudott már fogadni. Ebben az évben a telefont is bevezették a fürdőtelepre. 1913-ban a telep a belügyminiszter rendelete értelmében a gyógyfürdő-státuszt is megkapta, aminek előnye abban mutatkozott meg, hogy ezáltal jogosult lett gyógydíjak szedésére, valamint az épülő villák házadómentessége tizenkettőről húsz évre emelkedett. 1914-re elkészült a telep alagcsövezése, és lezárult a kikötő építésének első szakasza. A legtöbb gyalogút salakozása is befejeződött. A világháború éveiben nagyobb beruházások nem történtek, a társas élet is visszafogottabb lett. 
Elsősorban jótékony célú összejöveteleket tartottak a hadiárvák és a sebesültek segélyezésére. (STIRLING 1990:250-251) Amivel nehezen küzdöttek meg a közösségek, az a homokos partból adódott: a finomszemcsés homok az északi-északnyugati szelek révén jól be tudta teríteni a falut. Hunyady gróf ugyan a kastélya előtti útszakaszt folyamatosan locsoltatta, de a település többi részén ez még váratott magára. (GYULAY 1911:4, 1911:316)

\section{0. ábra. Balatonszemesi partrészlet 1914 előtt}

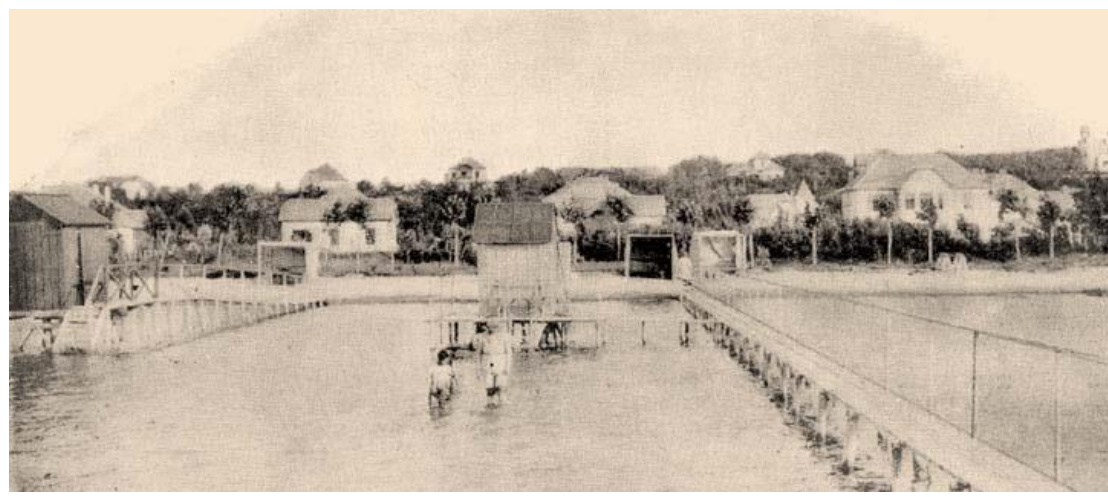

Forrás: REISZIG 1914:42-43

\section{7. Összegzés: A berényi és szemesi fejlesztések a dél-balatoni fürdőélet tükrében}

Látható az áttekintésből, hogy a dél-balatoni Hunyady-birtokokon jelentős fürdőfejlesztés indult meg a századforduló körüli évtizedekben. A hatalmas birtokokkal rendelkező grófok felismerték az ebben rejlő üzleti lehetőséget, amit be is tudtak illeszteni az uradalmi gazdasági rendszerükbe. A fürdőről, a fejlesztésekről mindig a grófok mondták ki a végső szót, míg a végrehajtás a helyi tiszttartókra maradt. Az uradalom jövedelmi rendszerében nagyon fontos volt, hogy a növekvő számú fürdővendég ellátása jelentős mértékben a földesúri majorságokból történt. A fürdőfejlesztés kezdeményezője a gróf volt, de ahogy a falusi közösségek, a parasztok, a polgári közösségek, illetve a fürdöegyesületek létrejöttek, a rendszer egyre inkább önjáróvá vált. Kétségtelen tény, hogy az 1910-ben 1419 lakosú Balatonberény és a 841 lakosú Balatonszemes népességszámuk alapján nem voltak kiemelkedő települések, de a fürdőfejlesztésekben igen komoly szerep jutott nekik. (NÉPSZÁMLÁLÁS 1910:62, 1910:65)

A ránk maradt statisztikai adatokból az látszik, hogy mindkét település sikeresen bekapcsolódott a fürdörendszer kiépítésébe. Az 1907. évi adatok alapján egyértelmü, hogy Siófokkal nem versenyezhetett Berény és Szemes, de az állandó vendégek és a szállodák számát tekintve Berény az elsők között volt; Szemes pedig, némileg kései indulással, egyre jobban fejlödött. 1907-ben a balatonberényi négy szállodánál csak Siófokon volt több, míg Fonyód és Földvár érte el a berényi szállodaszámot, a többiek esetében még kevesebb épült föl. (KANYAR 1978:152 alapján) A nagy fellendülés után azonban a háború előtti években a látogatottságot illetően jelentős változások figyelhetök meg. 
1. táblázat. A dél-balatoni települések ún. állandó jellegü fürdővendégeinek száma (1911-1913)

\begin{tabular}{|l|c|c|c|}
\hline Fürdőhely neve & $\begin{array}{c}\text { Bel- és külföldi } \\
\text { fürdővendégek száma } \\
\text { 1911-ben }\end{array}$ & $\begin{array}{c}\text { Bel- és külföldi } \\
\text { fürdővendégek száma } \\
\text { 1912-ben }\end{array}$ & $\begin{array}{c}\text { Bel- és külföldi } \\
\text { fürdővendégek } \\
\text { száma 1913-ben }\end{array}$ \\
\hline Balatonberény & 1659 & 1175 & 1323 \\
\hline Balatonkeresztúr & n.a. & 1024 & n.a. \\
\hline Fonyód & 1322 & 1213 & 531 \\
\hline Balatonboglár & 1148 & 1024 & 1115 \\
\hline Balatonszárszó & 982 & 958 & 1343 \\
\hline Balatonszemes & n.a. & 1053 & 927 \\
\hline Balatonföldvár & 1148 & 1093 & 4456 \\
\hline Siófok & 12116 & 6384 & 1295 \\
\hline
\end{tabular}

Forrás: FELSŐHÁZI IROMÁNYOK 1927:132-133 alapján

Látható a fenti táblázatból, hogy a háború elötti évekre sok helyen jelentősen megcsappant az állandó fürdővendégek száma, voltak olyan települések, ahol felére vagy harmadára esett vissza a vendégszám. A külföldi vendégek szinte teljesen elmaradtak. Ezzel párhuzamosan ugyanakkor az ún. ideiglenes fürdővendégek száma több helyen növekedett. Lényegében az egész déli partra jellemző folyamatot láthatunk. Okai között a háború előtti évek általános drágaságát, a máshol is nagyszámban nyíló fürdők adta nyaralási lehetőségeket, illetve az előnytelenné váló adózási rendelkezéseket láthatjuk. (LUKÁCS 1942:288) Az alacsony vendégszámok persze azzal is összefüggenek, hogy „...nem lévén a bejelentési kötelezettség szabályrendeletileg szabályozva, a lakást adók, úgy a villa tulajdonosok a bejelentéseket lanyhán teljesitik." - jegyezte meg a megye hivatalos lapjában. (SHL 1912. 11. 14.)

Megvizsgáltuk azt is, hogy az 1910. évi népszámlálás foglalkozási adatai szerint mennyire látszik a változás a két falu esetében. Szignifikáns különbséget nem tudtunk kimutatni azon falvakkal szemben, amelyek a Balatontól délebbre helyezkedtek el. Berényben és Szemesen a foglalkozási rendszerben 70-80\%-ban továbbra is a mezőgazdasággal foglalkozók voltak jelen. Az is kétségtelen ugyanakkor, hogy az a századforduló körüli évtizedekben az iparban és a kereskedelemben foglalkozók száma emelkedett. (NÉPSZÁMLÁLÁS 1910:62-70, T. MÉREY 1990) Mindebből arra lehet következtetni, hogy a századforduló utáni években a társadalmi munkamegosztás e térségben még gyerekcipőben járt, vagyis olyan gazdákat láthatunk, akik esetében megmarad a létbiztonság szempontjából oly fontos paraszti kisüzem, de ugyanakkor termékeikkel egyre nagyobb mértékben tudnak bekapcsolódni az ellátásba, illetve a vendégfogadással is plusz jövedelemre tehettek szert. Mutatja ugyanakkor a változásokat, hogy Szemes esetében a vizsgált korszakban a kisbirtokosok száma a felére olvadt,

S végül említsük meg, hogy a 20. század első évtizedében már az 1904-ben megalakult Balatoni Szövetség, (ZM 1904. 07.31, PAKSY 2016:323) a helyi közösségek, a földbirtokosok mellett a megyék is felismerték a technikai fejlesztések szükségességét. Ennek egyik jele az áramellátás kialakítása volt. Az első világháború elötti években már tervek születtek egy Szántód központú áramtermelö megépítéséröl. A háború alatt a viszonyok megváltoztak, ugyanakkor az elképzelések horizontálisan szélesedtek: végül 1917. február 18-án Budapesten alakult meg a 
Balatonvidéki Villamosmüvek Részvénytársaság, gróf Batthyány Lajos, a Balatoni Szövetség elnökének vezetésével. A társaság székhelye Balatonfüredre került. A részvényjegyzők között Balatonberényböl ott volt a korábban már említett Armuth Nathan szállodatulajdonos és Páli Lajos vendéglö- és hoteltulajdonos, Balatonszemesről pedig 13 nyaralótulajdonos és földbirtokos. (B 1917. 04. 01.) Végül is az erőmű nem a déli, hanem az északi parton, Aszófön épült meg, ahonnan a déli partra fektetett mederkábelen keresztül szállították az áramot, s a Siófok-Balatonfenyves szakaszon épült ki az ellátó rendszer. (ANTAL 2014:52) Somogy megye számára nagy feladat volt a parti menti települések egészséges ivóvízzel való ellátásának megszervezése, kiépítése. Jó tapasztalatok voltak ugyanakkor a Kaposvár-Fonyód, illetve a Somogyszob-Balatonszentgyörgy vasút hosszú távú hatásairól: a napi több állandó motoros vonat indítása jelentősen emelhette a fürdőzők számát. (SHL 1911. 11. 16.)

\section{Irodalomjegyzék}

ANTAL, I. (2014): A magyar villamosenergiaipar 1896-1914. Budapest. Magyar Tudománytörténeti Intézet

BALATONSZEMESI FÜRDÖEGYESÜLET (2009): Czirják Mariann - Hergárné Mády Katalin - Buday Miklós - Dobozy Dánel (szerk.): Balatonszemesi Fürdöegyesület. Centenáriumi Emlékkönyv. Budapest

BALÁZS-KOVÁCS, S. (2013): A tolnai nemesség fürdőélete a reformkorban. In: Kriston Vizi József (szerk.): Dél-dunántúli dolgozatok. Dombóvár. pp. 206-223.

BARANYAI, S. (1959): A Balaton vízszintszabályozásának története. Hidrológiai Közlöny 69. (6) pp. 340-344.

BEÖTHY, F. (1979): A Dél-Balaton irodalmi és történelmi emlékhelyei. Iskola és Levéltár 11. Kaposvár

BOLEMANN, I. (1900): A Balatonparti fürdők és üdülőhelyek leírása. In: Bolemann István (szerk.): A Balaton tudományos tanulmányozásának eredményei. III. kötet, 4. rész. Budapest

BÖSZE, S. (2002): A szocializáció sajátos színterei. A dél-balatoni fürdőegyesületek a polgári korban. In: Tóth G. Péter (szerk.): Struktúra és városkép. A polgári társadalom a Dunántúlon a dualizmus korában. Veszprém. pp. 453-462.

BÖSZE, S. (1997): „Az egyesületi élet a polgári szabadság...”. Somogy megye egyesületei a dualizmus korában. Somogyi Almanach 53. Kaposvár.

BÖSZE, S. (1989): A dél-balatoni fürdőegyesületek történetéből (1890-1944). In: Kanyar József (szerk.): Somogy megye múltjából 1989. Levéltári Évkönyv 20. Kaposvár. 211-252.

EÖRY, B. (2008): Dokumentumok Balatonberény fürdőkultúrájáról. Somogyi Honismeret 38. (1) pp. 19-23.

ERDÖSI, F. (1982): Somogy megye közlekedési hálózatának kialakulása a XIX-XX. században. In: Kanyar József (szerk.): Somogy megye múltjából 1982. Levéltári Évkönyv 13. Kaposvár. pp. 157-212.

FELSÖHÁZI IROMÁNYOK (1927): Felsőházi irományok. A trianoni békében megállapított területen fekvő nevezetesebb gyógyfürdők vendégforgalma az 1911-13. években. IX. kötet, 275. szám. pp. 132-146.

ERDÖS, J. (1911): Magyar Fürdö-Kalauz. Tata

GALGÓCZY, K. (1855): Magyarország, a szerb vajdaság és a temesi bánság mezögazdasági statisztikája. Pest 
GÖCZE, R. (2014): Palin és Korpavár története a polgárosodás korszakában. In: Kaposi Zoltán (szerk.): Nagykanizsa. Városi monográfia III. (1850-1945). Nagykanizsa. pp. 665-702.

GYULAY, K. (1911): Faluszemes monográfiája. Magyar Gazdák Szemléje 16. (1911): 3. füzet, 184-188.; 4. füzet, 250-255.; 5. füzet. pp. 312-322.

HALÁSZ, I. (2010): A Balaton lecsapolása (18-19. század). História 32. (6-7) pp. 37-41.

HUDI, J. (1989): A balatoni fürdőkultúra a reformkorban. In: Bilkei Irén (szerk.): Közlemények Zala megye közgyüjteményeinek kutatásaiból 1988. Zalai Gyüjtemény 28. Zalaegerszeg. pp. 109-135.

HUSZÁR, M. (2016): Egy 120 éves nyaralóhely története. In: Huszár Mihály - Samuné Bogyó Hajnalka - Sándor Csaba - Vidák Tünde: Üdvözlet Balatonmáriafürdőröl! Képeslap-válogatás egy délnyugat-balatoni település múltjáról. Marcali. Balatonmáriafürdő Község Önkormányzata - Marcali Múzeum

KANYAR, J. (1978): A dél-balatoni fürdőkultúra kialakulásának történeti korszakai. In: Kanyar József (szerk.): Somogy megye múltjából 1978. Levéltári Évkönyv 9. Kaposvár. pp. 139-189.

KAPOSI, Z. (2019): Uradalmak, földbirtokok és birtokforgalom a Dél-Dunántúlon a 19. században. Budapest

KAPOSI, Z. (2014): Nagykanizsa gazdasági fejlődése (1850-1945). In: Kaposi Zoltán (szerk.): Nagykanizsa. Városi monográfia III. (1850-1945). Nagykanizsa. pp. 99-250.

KAPOSI, Z. (2002): Magyarország gazdaságtörténete 1700-2000. Budapest-Pécs

KÁROLYI, Z. (1973): Az egyes vízvidékek szabályozási munkáinak története. In: Ihrig Dénes (szerk.): A magyar vízszabályozás története. Budapest. pp. 151-280.

KÉPVISELÖHÁZI IROMÁNYOK (1887): Képviselöházi irományok. A Közmunka- és Közlekedésügyi Miniszter jelentése az Országgyüléshez a Keszthelytől Balatonszentgyörgyig vezetendő helyi érdekü vasút engedélyezése tárgyában. 1. kötet. 1-40. Budapest

KERTAI, E. (1974): Magyarország nagyobb vizépitési mütárgyai. Tavi kikötők. I. Balatoni kikötök. Budapest

KÓSA, L. (1999): Fürdöélet a Monarchiában. Budapest

KUNICS, ZS. (2009): Gabona piacz - Főtér - Erzsébet királyné tér. A nagykanizsai Erzsébet tér kiépülése, története a dualizmus korában. Zalai Múzeum 18. pp. 267-294.

LÓCZY, I. (1978): A balatoni fürdőkultúra kialakulásának történeti áttekintése, különös tekintettel a déli partra. In: Honfi István (szerk.): Somogyi Múzeumok Közleményei 3. (1978). Kaposvár. 315-334.

LUKÁCS, K. (1942): Adatok a Balatonvidék történetéhez. Balatonberény a legrégebbi somogyi parti fürdőhely. Balatoni Szemle. pp. 285-288.

PAKSY, Z. (2016): A balatoni idegenforgalom fejlődése a 20. század első felében. In: Bilkei Irén (szerk.): Zalai évszázadok. Tanulmányok és dokumentumok Zala megye történetéhez 2016. Zalai Gyüjtemény 80. Zalaegerszeg. pp. 323-339.

PATKOVICS, J. (1846): A harkányi hévíz és gyógyereje. In: A magyar orvosok és természetvizsgálók 6. vándorgyülésének történeti vázlata és munkálatai. Pécs. pp. 162-175.

PESTY, F. (2001): Somogy vármegye helynévtára. Kaposvár

REISZIG, E. (1914): Somogy vármegye községei. In: Csánki Dezső (szerk.): Magyarország vármegyéi és városai 14. Somogy. Budapest. pp. 30-179. 
REÖTHY, F. (1989): Adatok a szemesi posta-lóváltóállomás történetéhez. In: Sebestyén Kálmán (szerk.): Postamúzeumi Évkönyv 1989. Budapest

REÖTHY, F. (1990/a): Eötvös Károly szemesi nyaralója. In: Reöthy Ferenc-Stirling János (szerk.): Szemes. Tanulmányok Balatonszemes múltjáról és jelenéröl. Balatonszemes. pp. 377381.

REÖTHY, F. (1990/b): Szemes és környékének közlekedése. In: Reöthy Ferenc-Stirling János (szerk.): Szemes. Tanulmányok Balatonszemes múltjáról és jelenéről. Balatonszemes. pp. 183204.

RIGÓ, L. (2018): Balatonberény krónikája. Berényi Hirlap, 2018. március 15.

SCHOEDL, E. (1934): Balatonszemes Fürdöegyesület 1908-1933. Budapest

SLEICHER, V. (2014): Kulturális kölcsönhatások a Balaton térségében 1822-1960 között. Doktori disszertáció. ELTE BTK. Történettudományok Doktori Iskola

STIRLING, J. (1990): A villatelep fejlődése és a Szemesi Fürdőegyesület. In: Reöthy FerencStirling János (szerk.): Szemes. Tanulmányok Balatonszemes múltjáról és jelenéröl. Balatonszemes. pp. 231-264.

SZAPLONCZAY, M. (1914): A Balaton. In: Csánki Dezső (szerk.): Magyarország vármegyéi és városai 14. Somogy. Budapest. pp. 21-29.

SZAPLONCZAY, M. (1896): A Somogyi Balatonpart községei mint Nyaraló és fürdöhelyek. Kaposvár

SZAPLONCZAY, M. - VAJTHÓ, J. (1907): A balatoni fürdők és üdülőhelyek leírása. In: Kardos Ignác-Simalya Ferenc (szerk.): A Balaton összes fürdö és üdülöhelyeinek leírása a Balatoni Szövetség támogatásával. Budapest.

SZITA, L. (1973): Harkány fürdötörténet 1823-1973. Harkány

TARNÓCZKY, A. (2013): Hol, mi? Kanizsai házak és lakóik. Nagykanizsa. Digitális megjelenés: www.nagykar.hu

T. MÉREY, K. (1990): A gazdasági és társadalmi élet alakulása a számok tükrében. In: Reöthy Ferenc-Stirling János (szerk.): Szemes. Tanulmányok Balatonszemes múltjáról és jelenéröl. Balatonszemes. pp. 175-182.

T. MÉREY, K. (2012): A gróf Hunyady család Somogy megyei uradalmainak leltára 1822. Fontes Comitatis Simighiensis III. Kaposvár

UJVÁRY, I. (1914): Mezőgazdaság, állattenyésztés, szőlőmívelés, erdészet. In: Csánki Dezső (szerk.): Magyarország vármegyéi és városai 14. Somogy. Budapest. 301-343.

VARGA, P. Zs. (2021): A ceruzakereskedéstől a komlói szénbányászat megteremtésig. Engel Adolf vállalkozásai az 1840-es évektől az első világháborúig. In: Pelles Márton - Jakopánecz Eszter - Kaposi Zoltán (szerk.): Úton a jövőbe. Pécs. pp. 56-68.

VIRÁG, Á. (2005): A Sió és a Balaton közös története 1055-2005. Budapest.

\section{Hivatkozott statisztikai források}

GAZDACÍMTÁR (1893): Magyarország földbirtokosai és földbérlői. Budapest

GAZDACÍMTÁR (1895): A magyar korona országainak mezőgazdasági statisztikája. 2. kötet. Budapest, 1897.

GAZDACÍMTÁR (1911): Magyarországi Gazdaczímtár. Budapest, 1912.

MSÉ: Magyar Statisztikai Évkönyv 1900, 1905. 1911-13. Budapest 
NÉPSZÁMLÁLÁS (1910): A magyar szent korona országainak 1910. évi népszámlálása. 2. A népesség foglalkozása és a nagyipari vállalatok községenkint. Budapest, 1913.

\section{Levéltári és múzeumi források}

MNL SML IV. 1.h. 39. Ö. 282-283 = Magyar Nemzeti Levéltár Somogy Megyei Levéltára IV. 1.h. 39. Összeírások. 282-283. 1806. év.

MM A 254 = Marcali Múzeum. Adattár, A-254 lista

MM Tdgy. 2020.38.3 = Marcali Múzeum. Történeti Dokumentum Gyüjtemény, 2020.38.3.

Kataszteri térkép, 1865: Digitális változat: https://mapire.eu/hu/map/cadastral

\section{Hivatkozott sajtóanyagok}

AU = Az Ujság; B = Balaton; BV = Balatonvidék; BH = Berényi Hírlap; KT = Köztelek; $\mathrm{PH}=$ Pesti Hírlap; $\mathrm{SH}=$ Somogyi Hírlap; SHL = Somogy vármegye Hivatalos Lapja; SV = Sportvilág; SVM = Somogyvármegye; VV = Vadász- és Versenylap; V = Világ; ZM = Zalamegye 